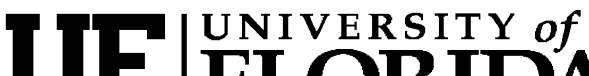 FLORIDA \\ IFAS Extension
}

\section{Cercospora Leaf Spot of Rose ${ }^{1}$}

\author{
Jozer Mangandi and Natalia A. Peres ${ }^{2}$ \\ Introduction
}

The primary foliar diseases of roses are black spot (caused by Diplocarpon rosae), powdery mildew (caused by Podosphaera pannosa) and Cercospora leaf spot (caused by Cercospora rosicola). Cercospora leaf spot is a little investigated disease, especially on varieties that belong to the groups of shrubs and ground cover roses. Although C. rosicola affects roses commonly, its impact is reduced when control measures for diseases such as black spot and powdery mildew is conducted. Other fungi such as Alternaria alternata, Colletotrichum capsici and Glomerella cingulata can also cause leaf spots on roses.

\section{Causal Agent and Geographical Distribution}

Fungi of the genus Cercospora are parasitic and infect a broad range of herbaceous plants. The main species affecting roses is Cercospora rosicola (Mycosphaerella rosicola, sexual stage). C. rosicola is distributed worldwide and was first reported on rose leaves in Florida in 1885.

\section{Symptoms}

Cercospora leaf spot is a disease often confused with black spot. Both diseases cause severe defoliation in heavily infected plants. The infection starts from the bottom of the canopy and progresses towards the tips where new growth is present. Lesions are primarily found in leaves but also in pedicels, stems, fruits and bracts. (See EDIS publication Cercospora Leaf Spot of Rose at http://edis.ifas.ufl.edu/PP268).

Symptoms of Cercospora leaf spot are circular spots usually 2-4 $\mathrm{mm}$ in diameter but single spots can be as large as $10 \mathrm{~mm}$ in diameter (Fig. 1a, 1b). The size is variable depending on the species or variety on which the lesions occur. When symptoms begin to appear, a small purplish area becomes apparent. In older lesions a small necrotic area develops and increases in size as the disease progress (Fig. 1b). At this point, the center of the spots turns tan to almost gray as the protoplast in the cells become brown and die.

1. This document is PP268, one of a series of the Plant Pathology Department, Florida Cooperative Extension Service, Institute of Food and Agricultural Sciences, University of Florida. Original publication date May 2009. Visit the EDIS Web Site at http://edis.ifas.ufl.edu.

2. Jozer Mangandi, graduate student, Department of Environmental Horticulture; Natalia A. Peres, assistant professor, Department of Plant Pathology, Gulf Coast Research and Education Center (REC)--Balm; Florida Cooperative Extension Service, Institute of Food and Agricultural Sciences, University of Florida, Gainesville, FL 32611

The use of trade names in this publication is solely for the purpose of providing specific information. UF/IFAS does not guarantee or warranty the products named, and references to them in this publication does not signify our approval to the exclusion of other products of suitable composition. All chemicals should be used in accordance with directions on the manufacturer's label.

The Institute of Food and Agricultural Sciences (IFAS) is an Equal Opportunity Institution authorized to provide research, educational information and other services only to individuals and institutions that function with non-discrimination with respect to race, creed, color, religion, age, disability, sex, sexual orientation, marital status, national origin, political opinions or affiliations. U.S. Department of Agriculture, Cooperative Extension Service, University of Florida, IFAS, Florida A. \& M. University Cooperative Extension Program, and Boards of County Commissioners Cooperating. Millie Ferrer, Interim Dean. 
In advanced necrotic lesions, groups of small tufts of conidiophores can be found. Conidiophores develop from masses of fungal tissue called stroma (Fig. 2a). Stromata are dark brown and appear as black dots over the necrotic area of the leaves. Under the microscope, cylindrical, almost straight, septate conidia can be observed (Fig. 2b).

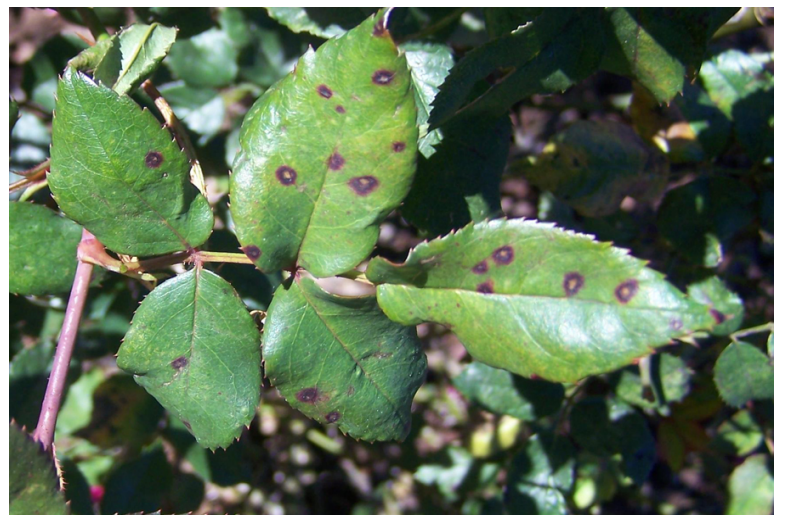

Fig. 1A. Leaves infected with Cercospora rosicola. Credits: J. Mangandi

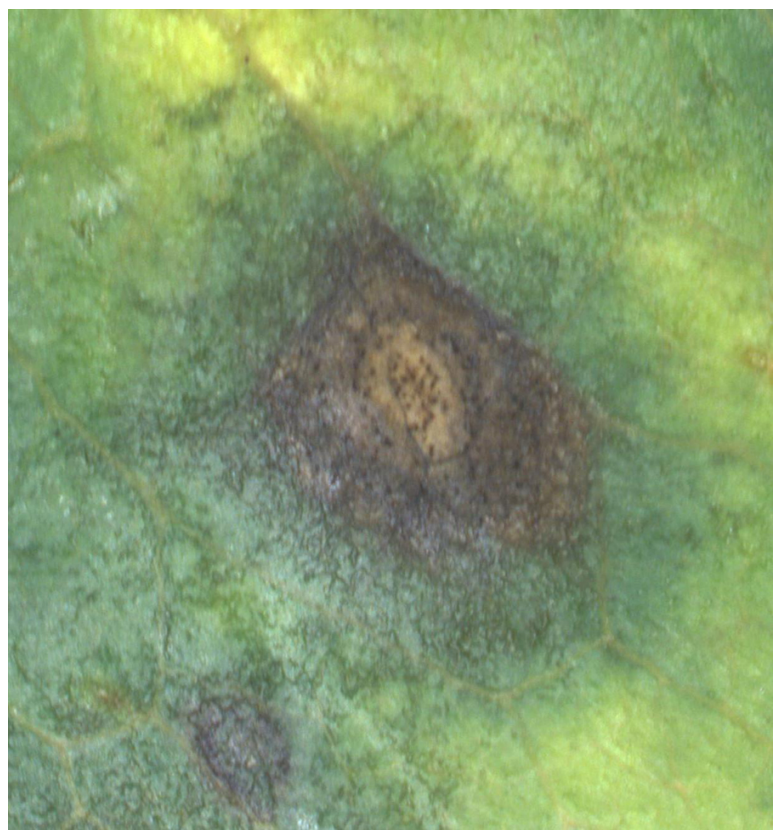

Fig. 1B. Cercospora leaf spot with typical circular lesion and a necrotic center, 10x. Credits: J. Mangandi

\section{Control}

Research trials have shown that Cercospora leaf spot is not significant when programs to control black spot and powdery mildew are used. Of 25 rose cultivars tested in Alabama, differences in susceptibility to black spot and Cercospora leaf spot were observed. All cultivars were susceptible to both

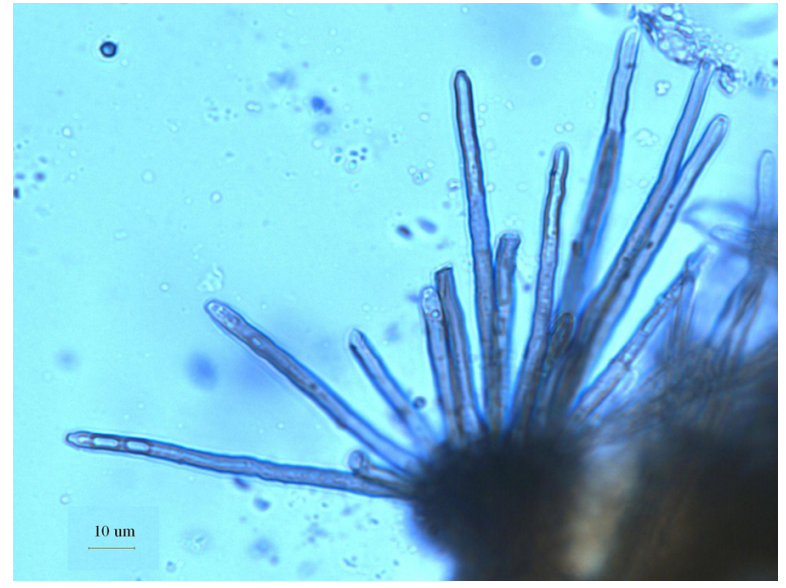

Fig. 2A. Conidiophores Credits: J. Mangandi

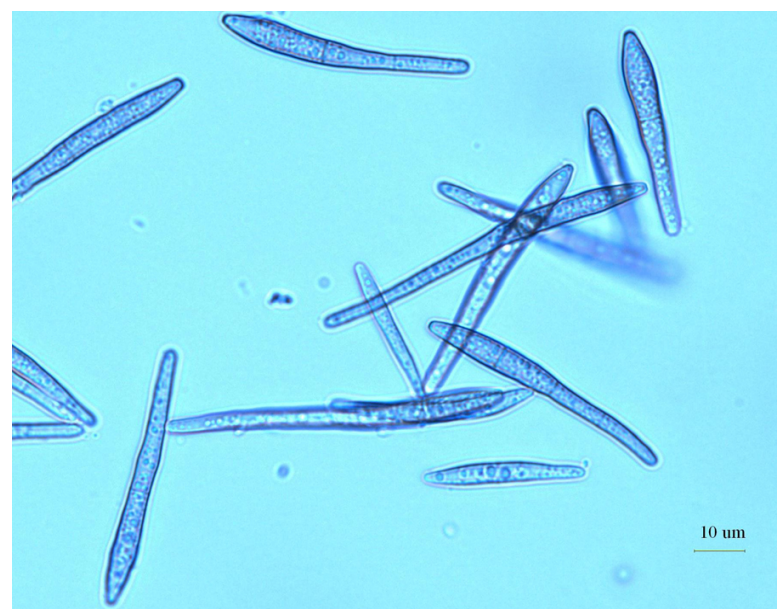

Fig. 2B. Conidia of Cercospora rosicola, 400x. Credits: J. Mangandi

diseases, predominantly black spot, but only two cultivars, 'Petite Pink Scotch' and 'The Fairy' showed persistent, severe symptoms of Cercospora leaf spot.

The shrub rose 'Fuchsia Meidiland' ${ }^{\circledR}$ was reported as a susceptible cultivar in Alabama and North Carolina. In an experiment conducted to evaluate commercial fungicides for the control of Cercospora leaf spot in this cultivar, it was concluded that products such as Compass ${ }^{\mathrm{TM}}$ and Daconil Ultrex ${ }^{\circledR}$ applied weekly as well as Eagle ${ }^{\circledR}$ and Heritage ${ }^{\circledR}$ applied twice monthly reduced severity of this disease to just few spots on the lower leaves.

Scheduled applications used to control black spot with fungicides such as Daconil Weather Stik ${ }^{\circledR}$, Immunox $^{\circledR}$, and Halt ${ }^{\circledR}$ also provide control of Cercospora leaf spot. Fungicides labeled for control of Cercospora leaf spot of roses in Florida are listed 
in Tables 1 and 2. For managing fungicide resistance, products with different modes of action should be used in rotations. All fungicides within the same group (with same number or letter) indicate the same active ingredient or similar mode of action.

Table 1. Fungicide products marketed for professional pesticide applicators for control of Cercospora leaf spot on roses.

\begin{tabular}{|c|c|c|}
\hline Trade name & Active ingredient & $\begin{array}{c}\text { Fungicide } \\
\text { group }\end{array}$ \\
\hline Spectro® 90 WDG & Chlorothalonil + thiophanate-methyl & M5+1 \\
\hline Daconilß Ultrex & \multirow[t]{4}{*}{ Chlorothalonil } & \multirow[t]{4}{*}{ M5 } \\
\hline Echo® 720 T\&O, Echo® ZN T\&O & & \\
\hline Esign $\AA 720$ & & \\
\hline $\begin{array}{l}\text { Prokoz® Mainsail } 6.0 \text { F, Prokoz } ® \\
\text { Mainsail WDG }\end{array}$ & & \\
\hline Champ® DP, Dry Prill & \multirow[t]{2}{*}{ Copper hydroxide } & \multirow[t]{2}{*}{ M1 } \\
\hline Champ® Formula 2 Flowable & & \\
\hline $\mathrm{COC} \circledast \mathrm{DF}, \mathrm{COC} \circledast \mathrm{WP}$ & Copper hydroxide + Copper oxychloride & M1 \\
\hline C-O-C-S® WDG & Copper oxychloride sulfate & M1 \\
\hline Dithane® -75 DF Rainshield & \multirow[t]{3}{*}{ Mancozeb } & \multirow[t]{3}{*}{ M3 } \\
\hline Fore® 80WP Rainshield & & \\
\hline Penncozeb® 75 DF T\&O & & \\
\hline Prokoz $\AA^{\circledR}$ Clevis & Mancozeb + Myclobutanil & $\mathrm{M} 3+3$ \\
\hline Maneb® 75 DF, Maneb® 80 WP & Maneb & M3 \\
\hline Procon® Z & Propiconazole & 3 \\
\hline Micro Sulf $\circledast$ & \multirow[t]{2}{*}{ Sulfur } & \multirow[t]{2}{*}{ M2 } \\
\hline Microthiol@ Dispers & & \\
\hline \multicolumn{3}{|c|}{$\begin{array}{l}\text { Fungicide Group (FRAC Code): Numbers (1-37) and letters (M) are used to distinguish the fungicidal mode of } \\
\text { action groups. All fungicides within the same group (with same number or letter) indicate same active } \\
\text { ingredient or similar mode of action. This information must be considered in making decisions about how to } \\
\text { manage fungicide resistance. M=Multi-site inhibitors, fungicide resistance is low. } \\
\text { Source: http://www.frac.info/ (Fungicide Resistance Action Committee, FRAC). } \\
\text { Be sure to read a current product label before applying any chemicals. }\end{array}$} \\
\hline
\end{tabular}


Table 2. Fungicide products marketed for homeowners for control of Cercospora leaf spot on roses.

\begin{tabular}{|c|c|c|}
\hline Trade name & Active ingredient & Fungicide group \\
\hline $\begin{array}{l}\text { Hi-Yield® Captan Fungicide, Bonide® Captan fruit and } \\
\text { Ornamental }\end{array}$ & Captan & M4 \\
\hline $\begin{array}{l}\text { Ferti-lome } \AA \text { Liquid fungicide, Bonide } \AA \text { Fung-onil } \\
\text { Multipurpose Fungicide, Monterey } \AA \text { Bravado } \\
\text { Fungicide, Ortho } \AA \text { Garden Disease Control }\end{array}$ & Chlorothalonil & M5 \\
\hline Monterey ${ }^{\circledR}$ Liqui-Cop & Copper ammonium complex & M1 \\
\hline $\begin{array}{l}\text { Ferti-lome } \AA \text { Blackspot Powdery Mildew Control, } \\
\text { Hi-Yield®Copper Fungicide }\end{array}$ & Copper hydroxide & M1 \\
\hline $\begin{array}{l}\text { Bonide } \AA \text { Copper Dust or Spray, Dexol® Bordeaux } \\
\text { Powder }\end{array}$ & Copper Sulfate & M1 \\
\hline Bonide ${ }^{\circledR}$ Mancozeb Flowable & Mancozeb & M3 \\
\hline 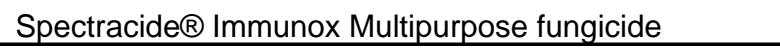 & Myclobutanil & 3 \\
\hline $\begin{array}{l}\text { Bonide } \AA \text { Rose Rx } 3 \text {-in-1, Ferti-lome } \AA \text { Triple Action } \\
\text { Plus, Monterey } \AA 70 \% \text { Neem oil }\end{array}$ & Neem Oil & $\mathrm{NC}$ \\
\hline Bonide® Remedy & Potassium Bicarbonate & $\mathrm{NC}$ \\
\hline Ferti-lome $\AA$ Systematic Fungicide, Bonide $\AA$ Infuse & Propiconazole & 3 \\
\hline $\begin{array}{l}\text { Bonide } ₫ \text { Sulfur Plant Fungicide, Ferti-lome }{ }^{\circledR} \text { Dusting } \\
\text { Sulfur, Green Light }{ }^{\circledR} \text { Wettable Dusting Sulfur, } \\
\text { Hi-Yield® Dusting Wettable Sulfur, Safer Garden } \AA\end{array}$ & Sulfur & M2 \\
\hline $\begin{array}{l}\text { Fungieide } \\
\text { Bayer® Advanced Garden Disease Control for Roses, } \\
\text { Flowers \& Shrubs }\end{array}$ & Tebuconazole & 3 \\
\hline $\begin{array}{l}\text { Ferti-lome } \AA \text { Halt Systemic Fungicide, Green Light } \circledast \\
\text { Systemic Fungicide. }\end{array}$ & Thiophanate-methyl & 1 \\
\hline Ortho $₫$ Rose Pride Rose \& Shrub Disease Control & Triforine & 3 \\
\hline Ziram $® 76$ DF, Ziram $®$ granuflo & Ziram & M3 \\
\hline \multicolumn{3}{|c|}{$\begin{array}{l}\text { Fungicide Group (FRAC Code): Numbers (1-37) and letters (M) are used to distinguish the fungicidal mode of } \\
\text { action groups. All fungicides within the same group (with same number or letter) indicate same active ingredient } \\
\text { or similar mode of action. This information must be considered in making decisions about how to manage } \\
\text { fungicide resistance. M=Multi-site inhibitors, fungicide resistance is low; NC= not classified. Source: } \\
\text { http://www.frac.info/ (Fungicide Resistance Action Committee, FRAC). } \\
\text { Be sure to read a current product label before applying any chemicals. }\end{array}$} \\
\hline
\end{tabular}

